\title{
Analysis of information on rheumatology from a selected Internet forum in the context of the need for telemedicine solutions
}

\author{
Rafał Szpakowski ${ }^{1}$, Maria Maślińska ${ }^{1}$, Grażyna Dykowska², Patrycja Zając ${ }^{3}$ \\ ${ }^{1}$ Early Arthritis Clinic, National Institute of Geriatrics, Rheumatology and Rehabilitation in Warsaw, Poland \\ ${ }^{2}$ Department of Public Health, Faculty of Health Sciences, Medical University of Warsaw, Poland \\ ${ }^{3}$ Department of Clinical Nursing, Faculty of Health Sciences, Medical University of Warsaw, Poland
}

\begin{abstract}
Objectives: The aim of this study was to determine how often patients and undiagnosed people who complain of musculoskeletal system and rheumatic diseases look for knowledge contained on an Internet forum. Content analysis was used to identify the level of Internet users' activity in the rheumatology section, compared to other areas of medicine.

Material and methods: Material included information posted on the Internet forum established at http://medyczka.pl/. The method employed was a quantitative and qualitative analysis of the content. The method was based on qualitative assessment of the first post in each thread presented on the rheumatologic subforum, by assigning keywords, subjectively determined by the researcher, to such a post. For each keyword a specific definition was established, determining a situation in which a given keyword was used.

Results: The quantitative analysis qualified rheumatology in the last place in terms of Internet users' activity compared to other branches of medicine. The qualitative assessment of the rheumatologic forum indicated that the three most common keywords were joint pain (32), joints swelling (13), and schoolage (13). The three most common intentional keywords (arranged in order of their decreasing number) were diagnosis based on symptoms (29), interpretation of the laboratory test results (9), and how to deal with symptoms (8).

Conclusions: The analysis leads to the conclusion that the rheumatologic subforum, along with other subforums listed above, presents a critically low level of discussion. There is a large disproportion between the number of active and passive forum users, suggesting that numerous individuals search the forum for presented information. Based on the qualitative analysis of the information stocks of the rheumatologic subforum, it was established that most of the questions posted concerned young individuals, who complained of joint pain and swelling, and asked for a possible diagnosis based on the presented symptomatology, interpretation of the laboratory test results and alleviation of disease symptoms.
\end{abstract}

Key words: internet forum, rheumatology, content analysis, telemedicine.

\section{Introduction}

Communication constitutes a key element of achieving success in any field of activity, especially in the field of therapeutic practice - that is, the area of health care, in which an oversight, misunderstanding or delay in the circulation of the information may lead to catastrophic effects for human health and life [1, 2]. The literature emphasizes the immense potential of telemedicine, which undoubtedly has the ability to strengthen communication in the field of health care [3-6]. Still, such

Address for correspondence:

Rafał Szpakowski, Early Arthritis Clinic, National Institute of Geriatrics, Rheumatology and Rehabilitation, Spartańska 1, 02-637 Warsaw,

Poland, e-mail: rafszpakowski@gmail.com

Submitted: 14.10.2015; Accepted: 4.11.2015 
solutions raise doubts of an ethical, legal and practical nature [5].

The authors of the present paper performed research aiming to identify whether patients' demand for telemedical solutions, such as Internet counseling, exists. The research employed the content analysis method $[7,8]$ to the Internet forum, to identify whether potential rheumatologic patients or their relatives search the forum for information related to the state of their health (diagnosis, therapeutic methods, etc.) or they rather employ the forum in the social context (emotional discharge, sharing day-to-day problems, etc.). Obviously, common sense suggests that the information concerning the state of health should be, in the first place, obtained from a health professional and not from an Internet forum, where it is impossible to verify who provides advice. Yet, as the research performed by Gemius and Polskie Badania Internetu [9] reveals, if patients want to learn more on the issues of health, diseases or ailment treatment, most commonly they obtain the information from the Internet. It has to be noted that obtaining reliable, professional advice in this way is not always possible. From the perspective of public health, it would be therefore beneficial to establish a professional replacement in the place of the Internet forum, providing information on health and illness. Instead of utilizing "information noise" prevailing at the Internet forums, resulting in difficulty in selecting reliable and valuable information, it would be better to enable patients to take advantage of telemedicine solutions, provided that a high level of interest from various groups of stakeholders, including patients, exists. Analyzing the activity on the Internet forum and its character, the authors investigated whether present or future rheumatologic patients express, directly or indirectly, a need for virtual access to professional medical information.

\section{Aim of the study}

The aim of this study was to determine how often patients and undiagnosed individuals complaining of musculoskeletal system ailments and rheumatic diseases look for the knowledge contained in the internet forum resources. The researchers attempted to determine whether the evidence of such a search for knowledge might indicate a need for professional advice from experts in the field of rheumatology rendered via the Internet. This study was designed to assess the extent to which telemedicine solutions in practice could prove useful in helping patients to proceed further on the diagnostic path. Content analysis was used to: 1) identify the level of Internet users' activity in the rheumatology section, compared to sections concerning other areas of medicine and 2) establish subjects presented in the rheumatology section of the forum.

\section{Material and methods}

The analyzed material included information posted on the Internet forum [10] established at http:// medyczka.pl/ as of September $20^{\text {th }}, 2014$. The method employed was a quantitative and qualitative analysis of the content $[7,8]$. The level of interest of Internet users concerning rheumatologic subjects, compared to the subjects concerning other areas of medicine, was evaluated using the number of discussion threads ( $t$ ) and posts ( $p$ ) in the sections of the respective sections of the Internet forum. In addition, the number of posts per single thread $(p / t)$ was determined. Introduction of this parameter enabled it to be established whether the number of posts concerning each subject results from the high user activity within the formed threads or from the sheer number of threads that have never been developed (equivalent to a lack of discussion). The determination of the thematic scope of the presented content was achieved by way of a qualitative assessment of the first post in each thread presented on the rheumatologic subforum, by assigning keywords, subjectively determined by the researcher, to such a post. Researchers established for each keyword an interpretation of meaning which determined a situation in which a given keyword was used. Keywords were divided into two categories, based on the subject of the post (subjective keyword) and the probable intention of the post's author (intentional keyword).

The age of individuals publishing posts on the forum was determined whenever it was explicitly specified in the post or the description in the post indicated the age of the person. For a description indicating students, the term school age (up to 26 years of age) was assigned. The description old person (the age of 65 years or more) was assigned to persons identifying themselves as elderly or - grandfather/grandmother - old person. The description adulthood was assigned for individuals of age above 26 and below 65. If it was not possible to determine the person's age, no age description was attributed. The creation of the keywords consisted in explorative coding (a categorization formula was formed from the keywords, in the course of the assessment of the study material). The qualitative assessment was initially performed by one researcher, and then by another, who, based on the keywords established by the first researcher, assigned the keywords to the first post in each of the discussion threads. Such a method was used in order to assess the accuracy of the categorization formula. The degree of similarity of the second re- 
searcher's qualitative assessment to the one performed by the first researcher was $91 \%$. As it was possible for some of the threads, accidentally or due to the lack of the user's knowledge, to be placed erroneously in the rheumatologic section, in spite of their subject having no connection to rheumatology - the additional qualitative evaluation consisted in classification of each thread as thematically related or not to rheumatology (e.g. type of the illness described in the thread pointed to a condition of "cardiologic nature"). If the qualitative assessment led to the classification of the post as other than "rheumatologic", no keywords were assigned to that post, as the research concentrated on the rheumatologic subjects exclusively. The qualitative analysis was performed using Microsoft Excel 2010. Exclusively descriptive statistics were used.

\section{Results}

The qualitative assessment of the rheumatologic forum enabled the creation of the categorization formula consisting of 55 keywords divided into two categories: intentional and subjective keywords (Table I).

The quantitative analysis qualified rheumatology in the last place in terms of Internet users' activity (measured as the number of posts) compared to other areas of medicine. Meanwhile Internet users' activity on the forum, measured as the number of posts on each thread, was comparable to that concerning laryngology, ophthalmology, urology, neurology, surgery, gastrology, psychiatry and dermatology. Five-fold higher activity (measured as the number of posts per thread), compared to the fields described above, was noted in fields such as oncology, cardiology, allergology, pediatrics, and gynecology. Below, the details of the activity of the Internet users (arranged in order of increasing number of posts) in the different areas of the researched forum are presented in Table II.

The quantitative analysis of the content was also applied to the new data emerging in the process of qualitative content analysis - to the keywords themselves. The qualitative analysis concerned the first posts in 70 threads, with keywords assigned to 55, which were assessed as related to rheumatology (Table III).

The number of all keywords assigned to the posts starting a thread was 218 . The mean number of keywords per thread was 3.963, that is almost 4 keywords per first post in a thread. Three most common keywords (arranged in order of their decreasing number) were: joint pain (32), joints swelling (13), and schoolage (13). Three most common intentional keywords (arranged in the order of their decreasing number) are: diagnosis based on symptoms (29), interpretation of laboratory tests (9), and how to deal with symptoms (8).

\section{Discussion}

The review of the present scientific literature (researched via PubMed) yielded no data on research concerning the subject of our work and methodology employed by us. The only work that we can relate to is our own article [11], which - unlike our present work - did not concern a specific form of information exchange constituted by the Internet forum. The subject of referred paper concerned mass media, making it impossible to make a comparison between the results of the research described in both articles. Therefore the discussion in our present paper takes the form of critical elaboration or authors' commentary on the presented results. Internet users' activity (measured as the number of posts) on the rheumatology subforum (thematic section), compared to other subforums, presents decisively the lowest level and differs profoundly from the activity on the remaining subforums concerning other medical specialties.

Posts of the rheumatologic subforum constitute only $0.03 \%$ of the overall number of all posts on the studied forum, with subforums of other specialties constituting respectively from $4.17 \%$ to $4.98 \%$ of all posts, with the exception of the gynecology subforum, which accounts for $42.05 \%$ of all posts. Yet, the analysis of the number of posts separately from other statistical data produces a distorted picture of the real situation. Therefore, it is vital to pay attention to the number of posts on each of the threads. Analysis of this parameter is justified primarily because of the various epidemiology of different diseases. Some conditions are more common in the overall population, yielding diverse interest from patients. In such a situation, the number of posts per thread ( $p / t)$ can be very helpful, as it reveals whether a large overall number of posts is a result of the high activity within threads (which points to an intense exchange of views/observations/thoughts) or of a large number of new threads that were never expanded by consecutive users into a discussion. With a discussion being the essence of the forum, in its absence the existence of the forum loses its fundamental value.

Analysis of the number of posts per thread reveals that for rheumatologic, laryngological, ophthalmologic, urologic, neurologic, surgical, gastrological, psychiatric, and dermatologic subforums this parameter shows low values from 1.95 to 2.33. This means that for every started thread, on average two posts are produced, including the one that started the thread. This leads to the conclusion that the rheumatologic subforum, along with other above-listed subforums, presents a critically low level of discussion; each question posted produces, on average, one response. A high level of discussion is observed for the oncologic, endocrinological, cardiologic, allergologi- 
Table I. List of keywords with their established meaning

\begin{tabular}{|c|c|c|c|c|c|}
\hline $\begin{array}{l}\text { Total } \\
\text { number } \\
\text { of key- } \\
\text { words }\end{array}$ & $\begin{array}{l}\text { Name } \\
\text { of } \\
\text { keyword }\end{array}$ & Established meaning of keyword & $\begin{array}{l}\text { Name } \\
\text { of } \\
\text { keyword }\end{array}$ & Established meaning of keyword & $\begin{array}{l}\text { Total } \\
\text { number } \\
\text { of key- } \\
\text { words }\end{array}$ \\
\hline 32 & arthralgias & $\begin{array}{c}\text { arthralgia / arthritis regardless of the } \\
\text { location and nature of the pain* }\end{array}$ & $\begin{array}{l}\text { hormonal } \\
\text { replace- } \\
\text { ment } \\
\text { therapy } \\
(\mathrm{HRT})\end{array}$ & $\begin{array}{c}\text { information in the post that replace- } \\
\text { ment therapy could be responsible for } \\
\text { the pain relief* }\end{array}$ & 1 \\
\hline 29 & $\begin{array}{l}\text { diagnosis } \\
\text { based on } \\
\text { symptoms }\end{array}$ & $\begin{array}{l}\text { signs / symptom presented, with } \\
\text { a subsequent request for identifying the } \\
\text { condition based on those symptoms* }\end{array}$ & $\begin{array}{l}\text { erythema } \\
\text { multiforme } \\
(E M)\end{array}$ & $\begin{array}{c}\text { affected person diagnosed or being } \\
\text { diagnosed } \\
\text { with erythema multiforme* }\end{array}$ & 1 \\
\hline 13 & $\begin{array}{l}\text { joints } \\
\text { swelling }\end{array}$ & $\begin{array}{c}\text { a post includes term "swollen”, } \\
\text { "edematous", e.g. fingers, knee - } \\
\text { regardless of which joint has been } \\
\text { described* }\end{array}$ & $\begin{array}{c}\text { atopic } \\
\text { dermatitis }\end{array}$ & $\begin{array}{c}\text { affected person suffering from atopic } \\
\text { dermatitis* }\end{array}$ & 1 \\
\hline 13 & school age & $\begin{array}{l}\text { symptoms indicate that the person } \\
\text { affected is of broadly defined school } \\
\text { age (junior high, high school, college) } \\
\text { or the indicated age of such a person } \\
\text { does not exceed } 26 \text { years* }\end{array}$ & $\begin{array}{l}\text { fibromy- } \\
\text { algia }\end{array}$ & $\begin{array}{l}\text { affected person diagnosed or being } \\
\text { diagnosed with fibromyalgia* }\end{array}$ & 1 \\
\hline 9 & $\begin{array}{l}\text { interpre- } \\
\text { tation of } \\
\text { laboratory } \\
\text { tests }\end{array}$ & $\begin{array}{c}\text { the post concerns indirectly/directly } \\
\text { the interpretation of laboratory test } \\
\text { results* }\end{array}$ & $\begin{array}{l}\text { interverte- } \\
\text { bral discs } \\
\text { and sciat- } \\
\text { ica of the } \\
\text { shoulder }\end{array}$ & $\begin{array}{l}\text { terms "discopathy" and/or "sciatica } \\
\text { shoulder" used in the context of } \\
\text { diagnosis or initial diagnosis* }\end{array}$ & 1 \\
\hline 8 & $\begin{array}{l}\text { muscle } \\
\text { pain }\end{array}$ & $\begin{array}{c}\text { the post indicates a person complain- } \\
\text { ing of muscle pain, regardless of the } \\
\text { location* }\end{array}$ & $\begin{array}{l}\text { scleroder- } \\
\text { ma }\end{array}$ & $\begin{array}{c}\text { affected person diagnosed or being } \\
\text { diagnosed } \\
\text { with scleroderma* }\end{array}$ & 1 \\
\hline 8 & back pain & $\begin{array}{c}\text { terms "neck pain" and "back pain" } \\
\text { used" }\end{array}$ & $\begin{array}{l}\text { burning } \\
\text { bones }\end{array}$ & term "burning bones" used* & 1 \\
\hline 7 & adulthood & $\begin{array}{c}\text { age in the range above } 26 \text { years and } \\
\text { below } 60 \text { years* }\end{array}$ & $\begin{array}{l}\text { warping } \\
\text { bones }\end{array}$ & term "buckling/dial bones" used* & 1 \\
\hline 6 & $\begin{array}{l}\text { rheu- } \\
\text { matoid } \\
\text { arthritis }\end{array}$ & $\begin{array}{c}\text { term "RA" or "rheumatoid arthritis" } \\
\text { or } \\
\text { "rheumatic arthritis" used* }\end{array}$ & $\begin{array}{l}\text { chondro- } \\
\text { malacia of } \\
\text { the patella }\end{array}$ & $\begin{array}{c}\text { term "chondromalacia of patella" } \\
\text { used in the context of diagnosis or } \\
\text { initial diagnosis* }\end{array}$ & 1 \\
\hline 6 & $\begin{array}{l}\text { rehabilita- } \\
\text { tion }\end{array}$ & $\begin{array}{c}\text { "rehabilitation" used in the context } \\
\text { of withdrawal / alleviation of existing } \\
\text { pain / swelling* }\end{array}$ & $\begin{array}{l}\text { numbness } \\
\text { of the up- } \\
\text { per limb }\end{array}$ & term “upper limb numbness” used* & 1 \\
\hline 6 & $\begin{array}{l}\text { morning } \\
\text { stiffness }\end{array}$ & the term "morning stiffness" used* & $\begin{array}{l}\text { stiffening } \\
\text { of joints }\end{array}$ & $\begin{array}{c}\text { term "stiffness"* or "numb joints" } \\
\text { used* }\end{array}$ & 1 \\
\hline 5 & gout & gout diagnosed or being diagnosed* & $\begin{array}{l}\text { psoriatic } \\
\text { arthritis }\end{array}$ & $\begin{array}{l}\text { affected person diagnosed or being } \\
\text { diagnosed with psoriatic arthritis* }\end{array}$ & 1 \\
\hline 3 & $\begin{array}{l}\text { interpre- } \\
\text { tation of } \\
\text { imaging } \\
\text { examina- } \\
\text { tion }\end{array}$ & $\begin{array}{l}\text { the post concerns help in the inter- } \\
\text { pretation of imaging examination } \\
\text { (X-ray, ultrasound, etc. })^{\star}\end{array}$ & $\begin{array}{l}\text { jumped } \\
\text { bones }\end{array}$ & term “jumped bones” used* & 1 \\
\hline 3 & pregnancy & $\begin{array}{l}\text { the person affected by symptoms / } \\
\text { diseases is in the period of } \\
\text { pregnancy, childbirth, } \\
\text { or plans to become pregnant } \\
\text { in the near future* }\end{array}$ & $\begin{array}{l}\text { surgery } \\
\text { (questions } \\
\text { concerning } \\
\text { risk of) }\end{array}$ & $\begin{array}{c}\text { a request for a surgery risk assess- } \\
\text { ment, its legitimacy or possible } \\
\text { complications* }\end{array}$ & 1 \\
\hline
\end{tabular}


Table I. Cont.

\begin{tabular}{|c|c|c|c|c|c|}
\hline $\begin{array}{l}\text { Total } \\
\text { number } \\
\text { of key- } \\
\text { words }\end{array}$ & $\begin{array}{l}\text { Name } \\
\text { of } \\
\text { keyword }\end{array}$ & Established meaning of keyword & $\begin{array}{l}\text { Name } \\
\text { of } \\
\text { keyword }\end{array}$ & Established meaning of keyword & $\begin{array}{l}\text { Total } \\
\text { number } \\
\text { of key- } \\
\text { words }\end{array}$ \\
\hline 2 & $\begin{array}{c}\text { muscle } \\
\text { weakness }\end{array}$ & $\begin{array}{c}\text { In the post the term "muscle weak- } \\
\text { ness" is used" }\end{array}$ & $\begin{array}{l}\text { seron- } \\
\text { egative } \\
\text { arthritis }\end{array}$ & $\begin{array}{l}\text { term "seronegative arthritis", used in } \\
\text { context of diagnosis or suspicion* }\end{array}$ & 1 \\
\hline 2 & $\begin{array}{l}\text { osteoar- } \\
\text { thritis (OA) }\end{array}$ & $\begin{array}{l}\text { information about diagnosed or } \\
\text { suspected } \mathrm{OA}^{*}\end{array}$ & $\begin{array}{l}\text { rashes and } \\
\text { lesions }\end{array}$ & $\begin{array}{l}\text { term "spots" used regardless of the } \\
\text { location of the lesion* }\end{array}$ & 1 \\
\hline 2 & $\begin{array}{l}\text { jolting } \\
\text { bones }\end{array}$ & $\begin{array}{c}\text { In the post the term "jolting bones" } \\
\text { is used" }\end{array}$ & $\begin{array}{l}\text { frequent } \\
\text { infections }\end{array}$ & $\begin{array}{l}\text { affected person described as subject } \\
\text { to frequent infections* }\end{array}$ & 1 \\
\hline 2 & $\begin{array}{l}\text { lupus ery- } \\
\text { themato- } \\
\text { sus (SLE) }\end{array}$ & $\begin{array}{l}\text { the term "lupus" is used in the con- } \\
\text { text of the disease diagnosed/being } \\
\text { diagnosed* }\end{array}$ & $\begin{array}{l}\text { pharma- } \\
\text { cological } \\
\text { treatment }\end{array}$ & $\begin{array}{l}\text { relation on drugs used } \\
\text { in rheumatological disease* }\end{array}$ & 1 \\
\hline 2 & $\begin{array}{l}\text { juvenile } \\
\text { idiopathic } \\
\text { arthritis } \\
\text { (JIA) }\end{array}$ & $\begin{array}{l}\text { the term "juvenile idiopathic arthri- } \\
\text { tis" is used* }\end{array}$ & $\begin{array}{l}\text { how to } \\
\text { deal with } \\
\text { the symp- } \\
\text { toms }\end{array}$ & $\begin{array}{l}\text { the post concerns a question of how } \\
\text { to deal with stated complaints }\end{array}$ & 8 \\
\hline 2 & chlamydia & $\begin{array}{c}\text { statement that the person believes } \\
\text { that the cause of her ailment is } \\
\text { chlamydia and/or is being diagnosed } \\
\text { in this direction; or the infection was } \\
\text { confirmed* }\end{array}$ & $\begin{array}{l}\text { "seeking } \\
\text { good spe- } \\
\text { cialist" }\end{array}$ & $\begin{array}{l}\text { a post concerning the search for } \\
\text { "good"/"trusted" doctor, a request for } \\
\text { the recommendation of a physician/ } \\
\text { health facility; also posts suggesting } \\
\text { indirectly the need to find a "tried } \\
\text { and tested" medical doctor** }\end{array}$ & 7 \\
\hline 1 & $\begin{array}{l}\text { stinging } \\
\text { pain }\end{array}$ & $\begin{array}{l}\text { in a post the nature of pain is de- } \\
\text { scribed as "stinging"* }\end{array}$ & $\begin{array}{l}\text { educa- } \\
\text { tional } \\
\text { materials } \\
\text { and infor- } \\
\text { mation } \\
\text { about the } \\
\text { disease }\end{array}$ & $\begin{array}{c}\text { first post is to gather information } \\
\text { on any disease entity or actions } \\
\text { allowed/disallowed in a particular } \\
\text { disease entity** }\end{array}$ & 7 \\
\hline 1 & $\begin{array}{l}\text { rheuma- } \\
\text { toid factor }\end{array}$ & $\begin{array}{c}\text { the post concerns exclusively RF } \\
\text { issues* }\end{array}$ & marijuana & $\begin{array}{l}\text { the person declares taking } \\
\text { marijuana* }\end{array}$ & 1 \\
\hline 1 & urethritis & term "urethritis" used* & diagnostics & $\begin{array}{l}\text { query about how to diagnose the } \\
\text { disease or symptoms of the underly- } \\
\text { ing disease to distinguish from other } \\
\text { possible causes }\end{array}$ & \\
\hline 1 & $\begin{array}{l}\text { reactive } \\
\text { arthritis } \\
(\operatorname{Re} A)\end{array}$ & $\begin{array}{l}\text { term "reactive arthritis" used in the } \\
\text { context of affected person diag- } \\
\text { nosed/being diagnosed for ReA } A^{*}\end{array}$ & $\begin{array}{l}\text { doubts } \\
\text { concerning } \\
\text { the diag- } \\
\text { nosis }\end{array}$ & $\begin{array}{l}\text { the post contains questions suggest- } \\
\text { ing doubts about the correctness } \\
\text { of medical diagnosis or explicitly } \\
\text { expresses such doubts }{ }^{\star *}\end{array}$ & 2 \\
\hline 1 & $\begin{array}{l}\text { cervical } \\
\text { myelopa- } \\
\text { thy }\end{array}$ & $\begin{array}{l}\text { affected person diagnosed with } \\
\text { cervical myelopathy* }\end{array}$ & $\begin{array}{l}\text { emotional } \\
\text { catharsis }\end{array}$ & $\begin{array}{l}\text { the post is of emotional nature, asso- } \\
\text { ciated with a sense of helplessness, } \\
\text { loss, accompanied by despair }\end{array}$ & 2 \\
\hline 1 & $\begin{array}{l}\text { inflamma- } \\
\text { tion of the } \\
\text { intercostal } \\
\text { cartilage } \\
\text { (Tietze } \\
\text { disease) }\end{array}$ & $\begin{array}{l}\text { term "inflammation of the intercostal } \\
\text { cartilage" used* }\end{array}$ & $\begin{array}{l}\text { online } \\
\text { survey }\end{array}$ & $\begin{array}{l}\text { the post asks people with rheumatic } \\
\text { diseases to take an online survey }{ }^{\star \star}\end{array}$ & 2 \\
\hline 1 & $\begin{array}{l}\text { spondylop- } \\
\text { athy }\end{array}$ & $\begin{array}{l}\text { affected person suspected } \\
\text { of spondylopathy* }\end{array}$ & old person & $\begin{array}{l}\text { the age of } 60 \text { years or more } \\
\text { indicated* }\end{array}$ & 1 \\
\hline 1 & headache & the word "headache" used* & & & 1 \\
\hline
\end{tabular}


cal, pediatric and gynecological subforums - with an average number of posts per thread numbering from 11.24 to 13.89 .

Based on the qualitative analysis, aimed at assigning keywords to the first posts in threads, it was established that questions posted on the forum concerned mainly young individuals. The high activity of young people should not be considered a surprise in the light of the Patient in the Net report [9], in which it was stated that the websites concerning health and medical issues are most popular among users 24-35 years old. The number of views of the rheumatologic subforum shows how disproportionate is the passive use (number of views) to the active use (placing posts) of the forum. Assuming that each view represents a different person, it reveals that more people search for information than are able to provide it.

\section{Conclusions}

Based on the qualitative analysis of the information stocks of the rheumatologic subforum, it was found that most of the questions posted concerned young individuals, who complained of joint pain and swelling, and asked for a possible diagnosis based on the presented symptomatology, interpretation of the laboratory test results and alleviation of disease symptoms.

The qualitative analysis of the forum content, including comparing the number of views of particular threads
Table II. Number of threads ( $t$ ) and posts ( $p$ ) in particular sections of Internet forum medyczka.pl (September $20^{\text {th }}, 2014$ )

\begin{tabular}{|lccc|}
\hline $\begin{array}{l}\text { Names of sections } \\
\text { on internet forum } \\
\text { medyczka.pl }\end{array}$ & $(\mathrm{t})$ & $(\mathrm{p})$ & $\begin{array}{c}\text { Average } \\
\text { number of } \\
\text { posts per } \\
\text { threads (p) / (t) }\end{array}$ \\
\hline Rheumatology & 70 & 163 & 2.33 \\
\hline Oncology & 1588 & 21208 & 13.36 \\
\hline Endocrinology & 1872 & 21479 & 11.47 \\
\hline Cardiology & 1868 & 21686 & 11.61 \\
\hline Allergology & 1640 & 21721 & 13.24 \\
\hline Pediatrics & 1948 & 21890 & 11.24 \\
\hline Laryngology & 11112 & 21984 & 1.98 \\
\hline Ophthalmology & 11184 & 22565 & 2.02 \\
\hline Urology & 11614 & 23054 & 1.99 \\
\hline Neurology & 11710 & 23123 & 1.97 \\
\hline Surgery & 11927 & 23250 & 1.95 \\
\hline Gastrology & 11753 & 23527 & 2.00 \\
\hline Psychiatry & 23909 & 2.05 \\
\hline Dermatology & 25331 & 2.04 \\
\hline Gynecology & 214022 & 13.89 \\
\hline
\end{tabular}

Table III. Number of threads views on the rheumatologic subforum (only the threads classified as rheumatological) on the forum medyczka.pl (20th September 2014)

\begin{tabular}{|c|c|c|c|}
\hline $\begin{array}{l}\text { Page } \\
\text { views }\end{array}$ & Internet address of thread & $\begin{array}{l}\text { Page } \\
\text { views }\end{array}$ & Internet address of thread \\
\hline 352 & $\begin{array}{l}\text { http://medyczka.pl/bole-stopy-i-stawow- } \\
\text { skokowych-33627 }\end{array}$ & 1065 & $\begin{array}{c}\text { http://medyczka.pl/przewlekle-bole-miesni- } \\
\text { stawow-bol-32466 }\end{array}$ \\
\hline 374 & $\begin{array}{l}\text { http://medyczka.pl/dokuczliwe-bole-stawow-w-mlo- } \\
\text { dym-35483 }\end{array}$ & 1077 & http://medyczka.pl/bol-w-okolicy-kolana-8610 \\
\hline 393 & $\begin{array}{l}\text { http://medyczka.pl/luszczycowe-zapalenie- } \\
\text { stawow-i-starania-30233 }\end{array}$ & 1126 & http://medyczka.pl/bole-w-karku-5198 \\
\hline 396 & $\begin{array}{l}\text { http://medyczka.pl/postepowanie-fizjoterapeu- } \\
\text { tyczne-w-dnie-moczanowej-28376 }\end{array}$ & 1136 & http://medyczka.pl/bol-karku-10182 \\
\hline 457 & http://medyczka.pl/gozdziec-jak-wyleczyc-32770 & 1198 & $\begin{array}{l}\text { http://medyczka.pl/bol-miesni-przez-okolo- } \\
\text { 3-a-34704 }\end{array}$ \\
\hline 481 & $\begin{array}{l}\text { http://medyczka.pl/23-lata-bole-stawow- } \\
\text { plecow-33913 }\end{array}$ & 1266 & $\begin{array}{c}\text { http://medyczka.pl/reumatologiczne-zapalenie- } \\
\text { stawow-leczenie-3868 }\end{array}$ \\
\hline 553 & $\begin{array}{l}\text { http://medyczka.pl/czy-z-mieszana-choroba-tkan- } \\
\text { ki-33787 }\end{array}$ & 1273 & $\begin{array}{c}\text { http://medyczka.pl/problematyczna-pacjent- } \\
\text { ka-z-bolami-stawow-15268 }\end{array}$ \\
\hline 576 & $\begin{array}{l}\text { http://medyczka.pl/bol-stawow-nadgarstka-i-ko- } \\
\text { stek-33747 }\end{array}$ & 1461 & $\begin{array}{l}\text { http://medyczka.pl/twardzina-ukladowa-obja- } \\
\text { wy-3936 }\end{array}$ \\
\hline 609 & $\begin{array}{l}\text { http://medyczka.pl/bole-mostka-podczas-ru- } \\
\text { chow-i-16780 }\end{array}$ & 1468 & http://medyczka.pl/bole-miesni-i-stawow-3864 \\
\hline
\end{tabular}


Table III. Cont.

\begin{tabular}{|c|c|c|c|}
\hline $\begin{array}{l}\text { Page } \\
\text { views }\end{array}$ & Internet address of thread & $\begin{array}{l}\text { Page } \\
\text { views }\end{array}$ & Internet address of thread \\
\hline 615 & $\begin{array}{c}\text { http://medyczka.pl/dyskopatia-i-rwa-barkowa- } \\
\text { bardzo-35467 }\end{array}$ & 1548 & $\begin{array}{c}\text { http://medyczka.pl/co-oznacza-wynik-badan- } \\
\text { th-15004 }\end{array}$ \\
\hline 720 & http://medyczka.pl/bole-stawow-i-miesni-bez-29507 & 1571 & $\begin{array}{l}\text { http://medyczka.pl/prosze-o-zinterpretowan- } \\
\text { ie-wynikow-ana2-32173 }\end{array}$ \\
\hline 752 & $\begin{array}{l}\text { http://medyczka.pl/przewlekle-bole-stawow-24-la- } \\
\text { ta-26535 }\end{array}$ & 1602 & http://medyczka.pl/bole-stawow-14272 \\
\hline 855 & http://medyczka.pl/diagnoza-17356 & 1710 & http://medyczka.pl/silne-bole-miesni-i-glowy-5265 \\
\hline 873 & http://medyczka.pl/wyniki-badan-rtg-biodra-i-16518 & 1855 & $\begin{array}{l}\text { http://medyczka.pl/reaktywne-zapalenie-st- } \\
\text { awow-czy-chlamydia-6646 }\end{array}$ \\
\hline 890 & $\begin{array}{l}\text { http://medyczka.pl/zgrubienie-lewej-nocy-w-okoli- } \\
\text { cy-31750 }\end{array}$ & 1899 & $\begin{array}{l}\text { http://medyczka.pl/toczen-rumieniowaty-fizjotera- } \\
\text { pia-13967 }\end{array}$ \\
\hline 894 & $\begin{array}{l}\text { http://medyczka.pl/rumien-wielopostaciowy-ze- } \\
\text { spol-stevensa-johnsona-21831 }\end{array}$ & 1964 & http://medyczka.pl/bole-nadgarstka-3942 \\
\hline 915 & http://medyczka.pl/specjalista-reumatolog-18205 & 1973 & $\begin{array}{l}\text { http://medyczka.pl/bol-stawow-podc- } \\
\text { zas-tocznia-20572 }\end{array}$ \\
\hline 916 & $\begin{array}{l}\text { http://medyczka.pl/obrzeki-stawow-wyniki-wszyst- } \\
\text { kich-badan-17176 }\end{array}$ & 2227 & $\begin{array}{l}\text { http://medyczka.pl/silny-bol-kolan-przyczyna-niez- } \\
\text { nana-8567 }\end{array}$ \\
\hline 919 & $\begin{array}{l}\text { http://medyczka.pl/ana-o-plamistym-typie-swiece- } \\
\text { nia-20063 }\end{array}$ & 2297 & $\begin{array}{l}\text { http://medyczka.pl/po-jakim-czasie-dziala-mi- } \\
\text { lurit-21512 }\end{array}$ \\
\hline 952 & http://medyczka.pl/rzs-ciaza-16526 & 2299 & http://medyczka.pl/bol-lewej-reki-4477 \\
\hline 958 & http://medyczka.pl/problemy-skorne-i-kostne-18219 & 2365 & http://medyczka.pl/nie-rzs-co-9309 \\
\hline 962 & $\begin{array}{c}\text { http://medyczka.pl/ankieta-dotyczaca-radzenia-so- } \\
\text { bie-z-15701 }\end{array}$ & 2596 & $\begin{array}{l}\text { http://medyczka.pl/co-oznacza-wynik-czynnika- } \\
\text { rf-33741 }\end{array}$ \\
\hline 994 & $\begin{array}{l}\text { http://medyczka.pl/bieczenie-bol-zaczerwie- } \\
\text { nienie-kostek-wewnetrznych-19408 }\end{array}$ & 2639 & http://medyczka.pl/strzelanie-stawow-8631 \\
\hline 1008 & http://medyczka.pl/wysokie-aso-u-dziecka-16858 & 3832 & http://medyczka.pl/bole-stawow-pomocy-4944 \\
\hline 1031 & http://medyczka.pl/bol-biodra-5209 & 4533 & $\begin{array}{l}\text { http://medyczka.pl/jak-wyglada-wizyta-u-reumatolo- } \\
\text { ga-13755 }\end{array}$ \\
\hline 1035 & http://medyczka.pl/zwyrodnienie-stawow-5196 & 11521 & $\begin{array}{l}\text { http://medyczka.pl/bol-kostek-kolan-i-kregoslu- } \\
\text { pa-14196 }\end{array}$ \\
\hline 1049 & http://medyczka.pl/dna-moczanowa-25473 & 25258 & http://medyczka.pl/dna-moczanowa-12686 \\
\hline \multirow[t]{2}{*}{1063} & http://medyczka.pl/bole-kregoslupa-w-ciazy-4511 & & \\
\hline & Total page views & & 106351 \\
\hline
\end{tabular}

with the average number of posts per thread, led to the conclusion that the discussion on the rheumatologic subforum is conducted at a low level in terms of number of answers/advice - compared to other subforums - and that an information gap exists in the area of patient-health professional communication.

There is a large disproportion between the number of active and passive forum users, suggesting that numerous individuals search the forum for presented information. The observed information gap concerning potential/present/future rheumatologic patients and their families may have different causes - lack of understanding by the patient/lack of time for the phy- sician to provide full and complete information, disruption in interpersonal communication, and long waiting times for an appointment with a medical specialist. It seems that, regardless of the cause, the problem of this gap should be addressed using methods from the field of telemedicine. If telemedicine - virtual counseling - were employed, this would on numerous occasions help the patient decide to seek the help of a professional, which, in the case of rheumatic diseases, is vital for introducing early therapy and thus improving the prognosis (the "therapeutic window"). In the case of patients already diagnosed, telemedicine can provide for better illness management and psychological help 
for patients with limitations in daily life activities or in work or household duties as well as those with the greatest constraints of the musculoskeletal system and who remain at home.

The authors declare no conflict of interest.

\section{References}

1. O'Daniel M, Rosenstein AH. Patient Safety and Quality: An Evidence-Based Handbook for Nurses. Chapter 33. Professional Communication and Team Collaboration [online] http://www. ncbi.nlm.nih.gov/books/NBK2637/ [1.09.2015]

2. Rimal RN, Lapinski MK. Why health communication is important in public health Bulletin of the World Health Organization 2009; 87: 247-247. [online] doi: 10.2471/BLT.08.056713 http://www.who.int/bulletin/volumes/87/4/08-056713/en/ [1.09.2015]

3. Karlińska M, Masiarz P, Mężyk R. Przyspieszenie wdrażania technologii informacyjno-komunikacyjnych $w$ regionalnej ochronie zdrowia dzięki finansowemu wsparciu UE - Przykład województwa świętokrzyskiego. [online] http://rocznikikae. sgh.waw.pl/p/roczniki_kae_z35_13.pdf [1.09.2015]

4. Tejera Segura B, Bustabad S. A new form of communication between rheumatology and primary care: The virtual consultation. Reumatol Clin 2015 Feb 13. pii: S1699-258X(15)00005-4. doi: 10.1016/j.reuma.2015.01.003.

5. Maślińska M, Lisiewska I. Internet - instrument we współczesnej medycynie. Od publikacji elektronicznej do leczenia i diagnostyki. In: W kierunku gospodarki elektronicznej - wyzwania, narzędzia, dobre praktyki. Upowszechnianie wiedzy w warunkach gospodarki elektronicznej. Powichrowska B (ed.). Vol. 1, 194-199. Wyższa Szkoła Ekonomiczna w Białymstoku, Białystok 2014.

6. Ostrowska S. Telemedycyna i internet medyczny - wpływ nowych środków komunikacji na relacje interesariuszy systemu ochrony zdrowia. [online] http://www.ptzp.org.pl/files/ konferencje/kzz/artyk_pdf_2010/118_Ostrowska_S.pdf [1.09.2015]

7. Makowska M. Analiza danych zastanych. Wydawnictwo SCHOLAR, Warszawa 2013.

8. Hsieh HF, Shannon SE. Three approaches to qualitative content analysis. Qual Health Res 2005; 15: 1277-1288.

9. Gemius. Raport 2012. Pacjent w sieci. [online] http://pliki. gemius.pl/Raporty/2012/Raport_Pacjenci_w_sieci_20121.pdf [1.09.2015].

10. Forum internetowe. [online] http://medyczka.pl/[20.09.2014].

11. Szpakowski R, Zając P. Analysis of the information on rheumatology in the resources of Internet services of opinion-forming dailies and weeklies. Reumatologia 2014; 52: 231-237. 